\title{
報文
}

\section{大阪国際空港着陸側の航空機騒音による 機種判別に関する研究}

\author{
A Study on Discrimination of Aircraft Type by Approach noise \\ Landing to Osaka International Airport
}

大比賀 直 樹 ${ }^{*}$. 廣川満夫 ${ }^{*}$. 片 岡 昇 ${ }^{*}$ ·水 谷 博 ${ }^{*}$

\begin{abstract}
Transportable and fixed aircraft noise monitoring systems which record automatically peak levels and appearing times of aircraft noise flying over them are used in several places. But there is possibility that they record the sounds of a horn by car and a silen. If the monitoring systems are able to discriminate aircraft type by the method of pattern matching, they will not take the unnecessary sounds and the aircraft noise data will be more useful.

In this paper, the landing aircraft front and rear noise data which are recorded in the vicinity of approach course to Osaka International Airport are transformed to the spectrum data by Fast Foulier Transform, and they are decided aircraft type with the help of a discriminant analysis. The result of discremination for the data used for making the discriminant function is $98.2 \%$, it shows very high percentage. Moreover, the result of discrimination for the unknown data is good percentage of $86.5 \%$. These discriminating rates are no problem in practical use at a personal computer level.
\end{abstract}

\section{要旨}

最近，航空機騒音の測定を目的とした，固定あるいは可搬型の騒音測定装置が方々で使用されているが，これは 通常，あるレベル以上の騒音值（ピークレベル）とその発生時刻を自動的（無人）に記録するあので, 自動車のク ラクションやサイレンの音などあ記録される可能性がある.そこで, 航空機騒音のパターン認識の手法で, 機種を 判別することができるならば，このような誤りを排除し，航空機騒音の単なる記録データのみでなく，より有力な 騷音資料として役立てることができるはずである.

本研究は，このような目的で, 航空機騒音から機種を判別する可能性を, 大阪国際空港の着陸側で論じたもので ある. まず, 大阪国際空港着陸コース周辺において測定した航空機の前方ノイズと後方ノイズを，それぞれについ て高速フーリエ変換（F F T ）を行い, 周波数スペクトルデー夕を求め, それらのデー夕を判別分析法により機種 判別を行った．その結果，判別関数を作製するために用いたデータでは，判別率 $98.2 \%$ とかなり良い判別率で判別 され，さらに，判別関数作成に用いなかった未知データを入力した場合でも $86.5 \%$ と比較的高い判別率を得た。こ の結果は, 判別関数作成以外は全てパーソナルコンピュータにより計算処理されたもので, 簡単なシステムでも, 実行できるものと考えている.

1. はじめに

にあたって，まず着陸する航空機の前方および後方 イズを高速フーリエ変換等によって定帯域分析し，さ 航空機騒音から機種を判別するシステムを開発する らに同期加算処理 ${ }^{1}$ を行い得られた周波数スペクトル *関西大学 Naoki OHBIKA, Mitsuo HIROKAWA, Noboru KATAOKA, Hiroshi MIZUTANI 昭和63年 9 月 5 日受理 
デー夕を，統計的決定論の一手法である判別分析法 ${ }^{2)}$ を用いて機種判別を行った。なお，判別にあたっては 計算時間短縮を考え，判別に有効なパラメー夕のみを 抽出するよう考虑した。

また，判別システムをできるだけ簡単にするため， パーソナルコンピュータで全処理を行うことを試みた が, 容量および計算速度に問題があり, 判別関数作成 のみワークステーションで処理し, その結果をパーソ ナルコンピュータにデータベースとして登録し, 機種 判別を実行した. 判別システムの流れを図ー 1 に示す.

\section{2. 測定およびデータの前処理}

騒音測定は, 昭和59年から63年にかけて, 大阪市淀 川区三国の神崎川河川敷において行った。（図一2） 測定にあたって，騒音データをデータレコーダに収録 するとともに，写真測量法により測定地点から航空機 までの距離を求めるために写真撮影を,さらに航空機 の速度を求めるためにビデオ撮影む実施した，測定地

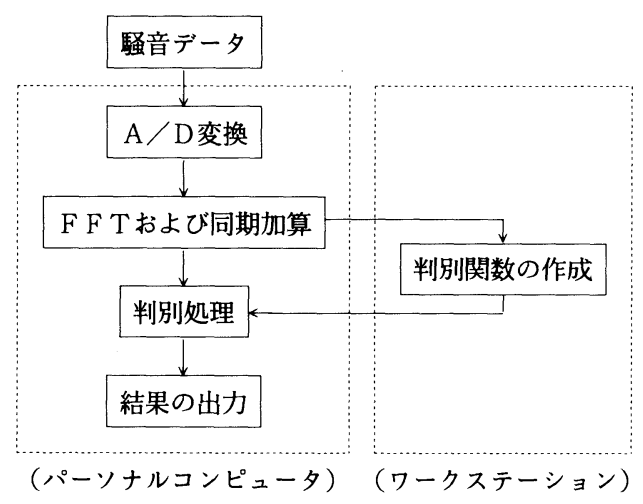

図ー 1 機種判別システム

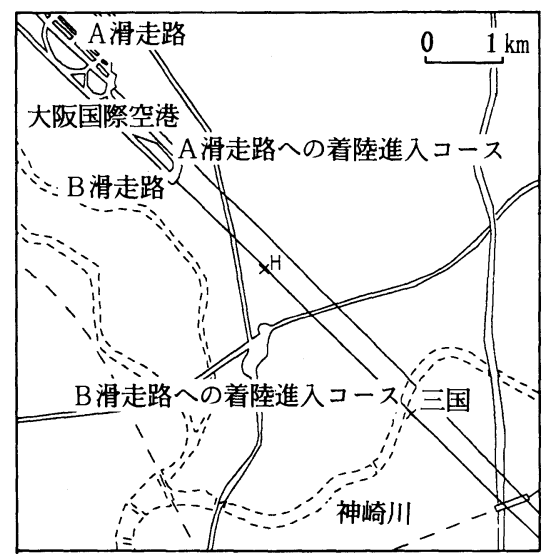

図ー2 測定場所および着陸進入コース
点より航空機までの距離（直距離）は，A滑走路を主 に使用するY S 11型機では約 $500 \mathrm{~m} ， \mathrm{~B}$ 滑走路に着陸

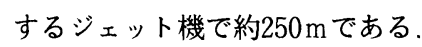

図一3は，航空機が測定地点の上空を通過している 時の様子を表している. bが測定地点からの最接近時 の位置とすると,この最接近時より以前に観測される 騒音が前方ノイズ，それ以後は後方ノイズと考えるこ とができる. 航空機騒音を構成する要素として, ジェッ トノイズ・ファンノイズ・エアフレームノイズなどが あるが, これらの各種ノイズから機種ごとの特徽を持 つノイズを抽出することが望ましい. 当研究室では, これまで機種ごとの特徴を持つ前方ノイズ（エンジン ブレードノイズその他) のみで判別を行っていたが33, 4), 今回は, 前方ノイズと, 比較的レベルの安定した後方 ノイズをパラメータとして用い，さらに同期加算処理 あ併用した。

図一 4 は, 測定地点で観測された航空機の時間波形 である. 前方ノイズの場合, 最接近時の 3 秒前から $\mathrm{A}$ /D变換（サンプリング周波数20.48 [kHz]）を開始 し，最接近時までのデータをコンピュータのメモリ上 に取り込む. 後方ノイズの場合は, 最接近時の 2 秒後 から同様にして A /D变換を開始し, 約 3 秒間のデー 夕を取り込むようにした。

まず前方ノイズにおいては，データの先頭から1024 点分の区間の高速フーリエ変換を行い, 256点ずつず

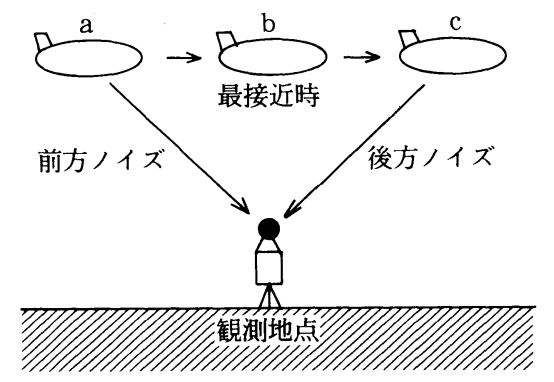

図一３航空機の通過

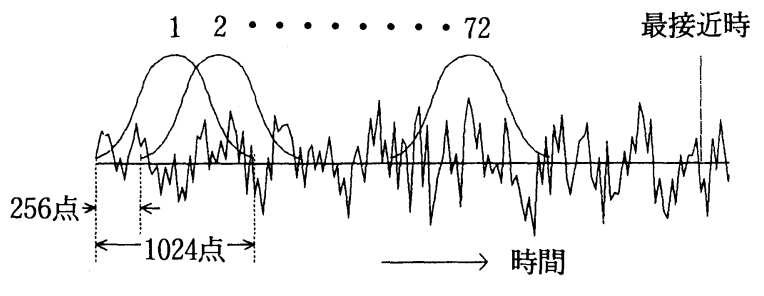

図-4 航空機騒音の時間波形 
らしながら同様に1024点分の区間の F F T を繰り返し 実行する．そして，合計72回のF F Tの後に，デシ心゙ ル加算 (同期加算) を行い, 512個 ( $0 \sim 10.22 〔 \mathrm{kHz}\rfloor$, $20[\mathrm{~Hz}]$ 間隔) の周波数バンドレベルを得る. しか し，実際に5.12〔k $\mathrm{kHz} 〕$ 以上の周波数領域には，機種 判別に必要と思われる特徽が現れにくいことや，また， 判別分析に用いるパラメータの個数は，必要最小限で あることが望ましいという理由により，周波数間隔も $40[\mathrm{~Hz}]$ として, 最終的に128個（ $0 \sim 5.08[\mathrm{kHz}]$, $40[\mathrm{~Hz}]$ 間隔) の周波数バンドレベルを前方ノイズ のパラメータとした。

後方ノイズにおいても同様に, デー夕の先頭（最接 近時の 2 秒後）から F F Tを実行し, 72回のデシベル 加算によって128個の周波数バンドレベルからなる後 方ノイズのパラメー夕を得た。

このように，航空機 1 機の通過騒音より，前方ノィ ズ128個, 後方ノイズ128個, 合計256個の周波数バン ドレベルが機種判別に必要なパラメータとして与えら れる。

\section{3. 判別関数の作成}

得られたバンドレベルデータが，どの機種のもので あるかを判別するために，判別分析法を用いた．判別 分析とは, 複数のグループが混在する母集団から無作 為に抽出したケースについて, その所属グループを求 める統計的手法である. 本研究では, 10機種について のバンドレベルデータが得られたので, 各機種ごとに バンドレベルデータの群を形成し, 判別に用いる最大 变数は，256個として判別分析を行うことにした。

機種判別においては，所属不明のケースが，どのグ ループに属するか決定するために，マハラノビスの汎 距離を利用する．マハラノビスの汎距離は，所属不明 のケースと各群との重心の距離を示し, この距離が最 小となる群に判別する. 所属不明のケースについての データを $x$ とし, $k$ 群の重心までのマハラノビスの汎 距離は，次式5)で与えられる.

$$
\mathrm{D}_{(k)}{ }^{2}=\left(x-\mu^{(k)}\right)^{\prime} \Sigma\left(x-\mu^{(k)}\right)
$$

$\Sigma:$ 分散共分散行列

$x$ : 所属不明のケース $\left(x_{1}, x_{2}, \ldots, x_{\mathrm{p}}\right)$

$\mu^{(k)}: k$ 群の重心 $\left(\mu_{1}{ }^{(k)}, \mu_{2}{ }^{(k)}, \ldots, \mu_{\mathrm{p}}{ }^{(k)}\right)$

$k$ : 群番号

この式の $x$ の 2 次の項は, $k$ によらず一定であるので, この式を最小にすることは，次式を最大にする $k$ を求 めることと同じとなる.

$$
z_{k}=x^{\prime} \quad \Sigma^{-1} \mu^{(k)}-\frac{1}{2} \mu^{\prime(k)} \Sigma^{-1} \mu^{(k)}
$$

したがって， Znが最大となるような $k$ に属するとして 判定する.

さらに,この $\mathrm{Z}_{(k)}$ に含まれる变数を, 計算時間短縮 と計算負担軽減を考えて, 判別に有効な变数のみに限 ることにした．いま, $q$ 個の変数 $x^{*}$ が $g$ 群の判別に用 いられているとする.ここに， $x^{*} に$ 含まれていない変 数 $x_{\mathrm{j}}$ を追加した場合の判別力の増加が有効かどうか

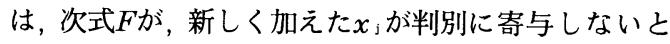
いう仮説のもとで, 自由度 $(g-1, n-g-q)$ の $F$ 分布に従うことを用いて検定を行う。

$$
F=\frac{n-g-q}{g-1} \cdot \frac{1-\Lambda\left(x_{j} \mid x^{*}\right)}{\Lambda\left(x_{j} \mid x^{*}\right)}
$$

$n:$ 総機数

$g:$ 群の数

\section{$\Lambda\left(x_{j} \mid x^{*}\right):$ 偏 $\Lambda$ 統計量}

$$
\Lambda\left(x_{j} \mid x^{*}\right)=\Lambda\left(x^{*}, x_{j}\right) / \Lambda\left(x^{*}\right)
$$

この $F$ 值があらかじめ設定した限界值より大きくな れば, $x_{j}$ を変数として追加し計算した.

\section{4. 結果および考察}

本論文においては, 判別の対象となる機種を表 1 に 示す 10 機種とした。これらの機種は, 現在大阪国際空 港に定期便として飛来する主な航空機であるが，この 中で, $\mathrm{B}-747$ が $\mathrm{PW}$ と $\mathrm{GE}$ の 2 種類に分類してある. この相違は，搭載しているエンジンによるもので， $\mathrm{P}$ WはPlatt\&Whitney社製の，GEはGeneral Electr ic社製のエンジンを搭載している. 機種判別において は，エンジンから発生する騒音の周波数スペクトルに よるところが大きい.したがって, 同一機種であって もエンジンが異なれば, 別のカテゴリーとして扱った． また，機体による分類について，基本型から胴体を延

表 1 判別対象機種と搭載エンジン

\begin{tabular}{|l|l|}
\hline \multicolumn{1}{|c|}{ 機 種 } & \multicolumn{1}{|c|}{ 搭載エンジン } \\
\hline B727 & P\&W-JT8D-15 \\
B737 & P\&W-JT8D-15 \\
B747PW & P\&W-JT9D系 \\
B747GE & GE-CF6-45/50 \\
B767 & GE-CF6-80A \\
L1011 & RR-RB211-22B \\
MD81 & P\&W-JT8D-209 \\
DC10 & P\&W-JT9D-59A \\
A300 & GE-CF6-50 \\
YS11 & RR-DART542 \\
\hline
\end{tabular}


長するなどの改良を加えた派生型（例えば， B - 747 $\mathrm{S} P ， \mathrm{~B}-747-300, \mathrm{~B}-767-300$ ）は，すべて基本 型に含めた。

図一 5 に, B-747 PW, B-747G E, Y S -11 の 前方および後方ノイズの72回の同期加算後の周波数ス ペクトルのデータを示す. B-747 PW, B $-747 \mathrm{GE}$ の前方ノイズの高周波域には, 前方ファンのブレード 枚数とその回転数によって特徴づけられるファン前方 ノイズのピークが，Y S - 11の前方ノイズの低周波域 には，4枚のプロペラの回転による特徴周波数が表れ ている。一方, 後方ノイズには, 全帯域にわたって前 方ノイズほど目立った特徵は存在しない，しかしなが ら，F検定により判別率の増加に寄与するであろうと 判定された判別関数の数は，全部で77個あり，そのう ち前方ノイズから得られたものは35個, 後方ノイズか らは42個であった．これは，前方ノイズより後方ノイ ズのほうがランダム性が小さく, 同一機種のバンドレ
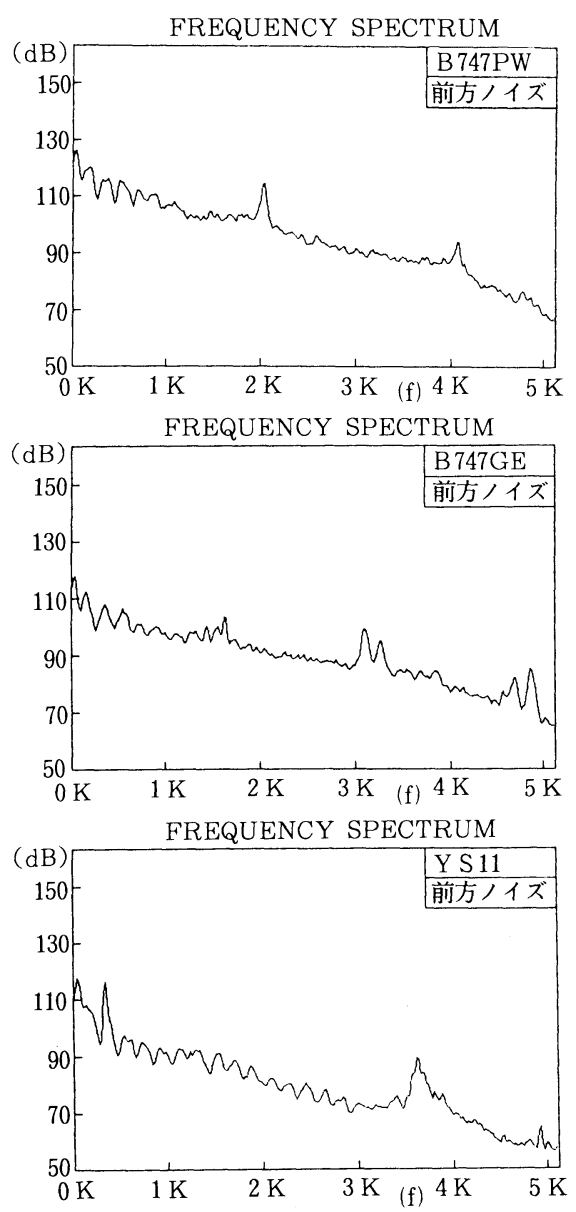

ベルのばらつきも少ないため，後方ノイズからより多 くの機種判別に有効な变数が採用されたと考えられる. また，周波数帯域の違いによる变数の数に着目すると， 前方・後方ノイズとも低周波成分で，バンドレベルの ばらつきが小さいため，この低周波成分についての変 数が多く含まれている.

こうして作成された判別関数を用いて判別を行った 結果を表 2 および表 3 に示す．表中左側縦列が，未知 入力としての機種名であり，上段横行が，それに対す る出力の機種名である．表2では，作成された判別関 数がどれほど機種ごとに分離できているかを確認する ために，判別関数を作成するのに用いたデー夕を入力 したときの判別結果を示し，表 3 は，作成された判別 関数に，判別関数作成に用いなかった末知デー夕を入 カしたときの結果である. また，表 4 は，判別関数作 成に用いたデー夕の機種ごとの, 直距離, 対地速度, および測定時の温度の, 平均と標準偏差を示す.
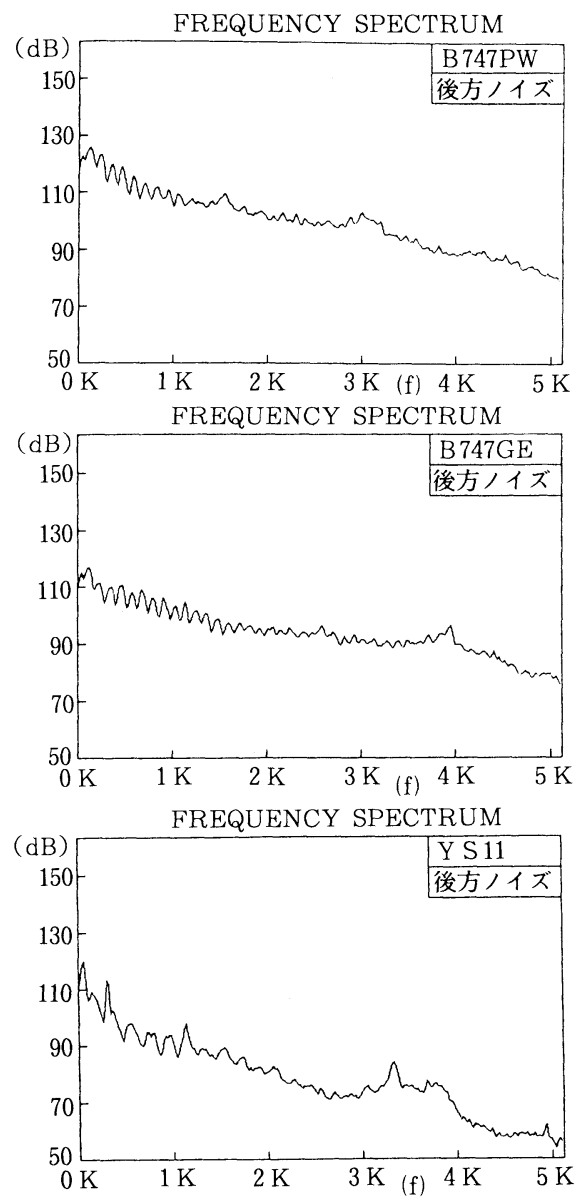

図ー5 B $747 \mathrm{PW} ， \mathrm{~B} 747 \mathrm{GE} ， \mathrm{Y} \mathrm{S} 11$ のパワースペクトラム（昭和59年 3 月） 
表 2 判別結果 (判別関数作成用データについての判別率〔\%])

\begin{tabular}{|c|r||r|r|r|r|r|r|r|r|r|r|}
\hline \multirow{2}{*}{ 機 種 } & \multicolumn{2}{|c|}{ 機数 } & \multicolumn{7}{|c|}{ 機 } \\
\hline & B727 & B737 & B747PW & B747GE & B767 & MD81 & DC10 & L1011 & A300 & YS11 \\
\hline B727 & 25 & 96.0 & & 4.0 & & & & & & & \\
\hline B737 & 6 & & 100.0 & & & & & & & & \\
\hline B747PW & 54 & & & 96.3 & & & & & 3.7 & & \\
\hline B747GE & 32 & & & & 100.0 & & & & & & \\
\hline B767 & 60 & & 1.7 & & & 96.6 & & & & 1.7 & \\
\hline MD81 & 9 & & & & & & 100.0 & & & & \\
\hline DC10 & 50 & & & & & & & 98.0 & & 2.0 & \\
\hline L1011 & 37 & & & & & & & & 100.0 & & \\
\hline A300 & 19 & & & & 5.3 & & & & & 94.7 & \\
\hline YS11 & 102 & & & & & & & & & & 100.0 \\
\hline
\end{tabular}

表 3 判別結果 (判別関数作成には全く関係のない未知データについての判別率[\%])

\begin{tabular}{|c|c|c|c|c|c|c|c|c|c|c|c|}
\hline \multirow{2}{*}{ 機＼cjkstart種 } & \multirow{2}{*}{ 機数 } & \multicolumn{10}{|c|}{ 種 } \\
\hline & & B727 & B737 & B747PW & B747GE & B767 & MD81 & DC10 & L1011 & A 300 & YS11 \\
\hline B727 & 2 & 50.0 & 50.0 & & & & & & & & \\
\hline B737 & 1 & & 100.0 & & & & & & & & \\
\hline $\mathrm{B} 747 \mathrm{PW}$ & 20 & 5.0 & 5.0 & 75.0 & & 10.0 & 5.0 & & & & \\
\hline B747GE & 10 & & & & 90.0 & 10.0 & & & & & \\
\hline B767 & 22 & & 9.1 & & 9.1 & 81.8 & & & & & \\
\hline MD81 & 2 & & 50.0 & & & & 50.0 & & & & \\
\hline DC10 & 8 & & & 12.5 & & & & 87.5 & & & \\
\hline L1011 & 6 & & & & & & & & 100.0 & & \\
\hline $\mathrm{A} 300$ & 5 & & 20.0 & & & & & & & 80.0 & \\
\hline YS11 & 28 & & & & & & & & & & 100.0 \\
\hline
\end{tabular}

表 4 判別関数作成に用いたデータと被判別データの平均および標準偏差

\begin{tabular}{|c|c|c|c|c|c|c|c|c|c|}
\hline & & \multicolumn{4}{|c|}{ 判別関数作成に用いたデータ } & \multicolumn{4}{|c|}{ 被判別データ } \\
\hline 機 種 & $=$ & 機 数 & 温 度 & 直距離 & 速 度 & 機 数 & 温 度 & 直距離 & 速 度 \\
\hline \multirow{2}{*}{ B727 } & 平均 & \multirow{2}{*}{25} & 13.5 & 244.0 & 73.3 & \multirow{2}{*}{2} & 21.2 & 248.4 & 60.7 \\
\hline & 標準偏差 & & 8.8 & 12.7 & 5.5 & & 2.8 & 3.2 & 3.1 \\
\hline \multirow{2}{*}{ B737 } & 平 均 & \multirow{2}{*}{6} & 23.0 & 319.8 & 66.2 & \multirow{2}{*}{1} & 21.6 & 257.7 & 64.2 \\
\hline & 標準偏差 & & 9.3 & 109.1 & 3.2 & & - & - & 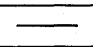 \\
\hline \multirow{2}{*}{ B747PW } & 平 均 & \multirow{2}{*}{54} & 17.4 & 256.6 & 72.8 & \multirow{2}{*}{20} & 22.2 & 264.0 & 71.9 \\
\hline & 標準偏差 & & 9.5 & 9.3 & 4.3 & & 0.9 & 9.8 & 4.9 \\
\hline \multirow{2}{*}{ B747GE } & 平 均 & \multirow{2}{*}{32} & 19.1 & 254.8 & 72.0 & \multirow{2}{*}{10} & 21.6 & 259.1 & 73.2 \\
\hline & 標準偏差 & & 9.2 & 8.6 & 3.4 & & 1.0 & 5.5 & 2.2 \\
\hline \multirow{2}{*}{ B767 } & 平 均 & \multirow{2}{*}{60} & 17.5 & 253.9 & 68.8 & \multirow{2}{*}{22} & 21.7 & 260.3 & 67.9 \\
\hline & 標準偏差 & & 9.2 & 6.2 & 4.1 & & 1.2 & 5.1 & 1.8 \\
\hline \multirow{2}{*}{ MD81 } & 平 均 & \multirow{2}{*}{9} & 15.2 & 248.8 & 70.4 & \multirow{2}{*}{2} & 22.7 & 255.5 & 70.6 \\
\hline & 標準偏差 & & 9.2 & 10.4 & 3.1 & & 0.7 & 3.9 & 0.4 \\
\hline \multirow{2}{*}{ DC10 } & 平 均 & \multirow{2}{*}{50} & 16.0 & 257.4 & 75.4 & \multirow{2}{*}{8} & 21.0 & 260.8 & 75.6 \\
\hline & 標準偏差 & & 9.4 & 7.6 & 5.8 & & 1.4 & 4.3 & 4.0 \\
\hline \multirow{2}{*}{ L1011 } & 平 均 & \multirow{2}{*}{37} & 14.4 & 258.8 & 75.3 & \multirow{2}{*}{6} & 21.9 & 261.0 & 77.3 \\
\hline & 標準偏差 & & 8.9 & 17.0 & 3.8 & & 1.5 & 5.6 & 4.7 \\
\hline \multirow{2}{*}{$\mathrm{A} 300$} & 平 均 & \multirow{2}{*}{19} & 16.4 & 244.4 & 70.2 & \multirow{2}{*}{5} & 21.6 & 250.9 & 63.4 \\
\hline & 標準偏差 & & 9.6 & 5.7 & 5.1 & & 1.7 & 3.8 & 2.2 \\
\hline \multirow{2}{*}{ YS11 } & 平 均 & \multirow{2}{*}{102} & 16.6 & 475.7 & 62.6 & \multirow{2}{*}{28} & 21.7 & 495.1 & 63.0 \\
\hline & 標準偏差 & & 9.9 & 37.9 & 4.1 & & 1.0 & 50.8 & 6.8 \\
\hline
\end{tabular}

注:単位は次の通り 温度 ; ${ }^{\circ} \mathrm{C}$ 直距離 $; \mathrm{m}$ 速度 $; \mathrm{m} / \mathrm{s}$ 
表 2 より, 全体の判別率は $98.2 \%$ と非常に高い判別 率が得られた。これは, 判別関数が機種ごとに良く線 形分離できていることを意味する.この判別率は, 文 献 4 ）の報告と同程度であるが, パラメータの数が約 $2 / 3$ で得られている.これは, デー夕を同期加算す ることで，機種ごとの特徴をより明確にできたためと 考えられる. 表 $3 に$ にいても, 全体の判別率 $86.5 \%$ と 高い率で判別できたといえる. 特に, Y S - 11と他の ジェット機とは, 完全に分離できた。これは，搭載エ ンジンがターボプロップとターボファンであり, 全く 構造が異なるので, 図一5からもわかるように, 周波 数スペクトルが大きく異なり, 完全に判別できたもの と思われる。

誤判別の原因としては，以下の 5 点が主に考えられ る.

(1) 測定時の気象条件の相違

(2) 飛行コースのばらつき

（3）搭載エンジンの形式と運用方法

(4) エンジン推力のばらつき

(5) 機体の形状

これらの原因を個々に検討すると, まず気象条件に ついては，測定時の最低気温が約 $7^{\circ} \mathrm{C} て ゙$ 最高気温が約 $32^{\circ} \mathrm{C}$ と大きな差がある. 図ー 6 に 9 月の B $-747 \mathrm{G} \mathrm{E}$ の同期加算後の周波数スペクトルを示す. 図一 5 は 3 月の測定データであるが, これらを比較すると,ファ ンノイズによる特徴周波数のピークが，9月のほうが 約 $200 \mathrm{~Hz}$ 高い，これは，エンジン推力が温度で差があ り，その影響ではないかと思われる。 また，湿度や風 を含めた気象条件が，騒音伝搬の減衰に影響を及ぼす ことも考えられる.

つぎに, 飛行コースのばらつきについて検討すると， 大阪国際空港に着陸する場合, 航空機は計器着陸装置 （ＩＬＳ）による誘導を受けるため，表 3 に示すよう

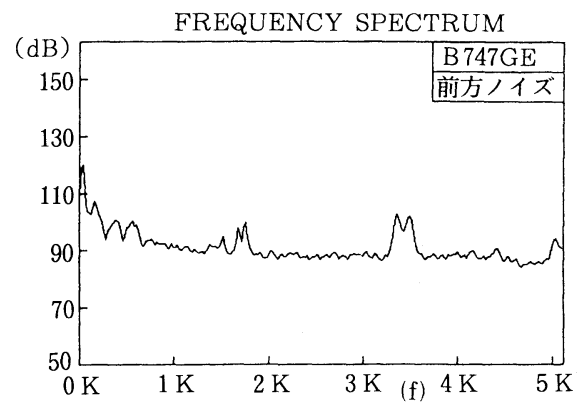

に直距離のばらつきは少ない，ただ，表 4 より B -73 7のデー夕には，A滑走路とB 滑走路に着陸するデー 夕が含まれ，直距離のばらつきが大きくなっている。 また，測定地点からみた $\mathrm{A}$ 滑走路の着地点は，B滑走 路より遠方にあり，エンジン推力のばらつきも大きい と推測できる. その結果, ばらつきの大きいデー夕か ら判別関数が作成され，判別の段階で他の機種が B 737に誤判別され判別率が低下したと考えられる.

(3)の搭載エンジンについては，表 1 に分類したとお りであるが, 特に B - 747に搭載されている P \& W J T 9 Dには- $7 \mathrm{~A},-7 \mathrm{AW},-7 \mathrm{Q},-7 \mathrm{R} 4 \mathrm{G}$ $2 \cdots \cdots$ と多くの種類があり，推力や騒音値が少しずっ 異なっている.またこれとは反対に，B-747 G E， B-767，A-300のように機種が異なっていても同種 のエンジンを搭載している場合もある。ささらに，エン ジンの着陸時における運用および(4)のエンジン推力の ばらつきに関して, 着陸機は I L S の誘導によって, 細かくエンジンの推力を調整するために測定地点の推 力は一定ではない．これらも誤判別の一因といえる.

最後に，機体の形状についてであるが, 航空機の着 陸時には，エンジンを絞るため航空機騷音に含まれる エアフレームノイズの割合が増加する，それゆえ，機 体の形状によるエアフレームノイズの差 ${ }^{6)}$ が，判別に 影響すると考えられる。.また, フラップや方向舵の操 作によっても騒音が变化し，判別に影響を与える.

これらの判別率低下の原因と考えられるもののうち， (3)と(4)の影響を取り除くため, 表 5 のようにエンジン 別の判別率を求めた結果, 全体で $92.3 \%$ と非常に高い 判別率を得た。

\section{5. まとめ}

パーソナルコンピュータを用いて，航空機騒音によ る機種判別を自動的に行う手法について述べたが，未

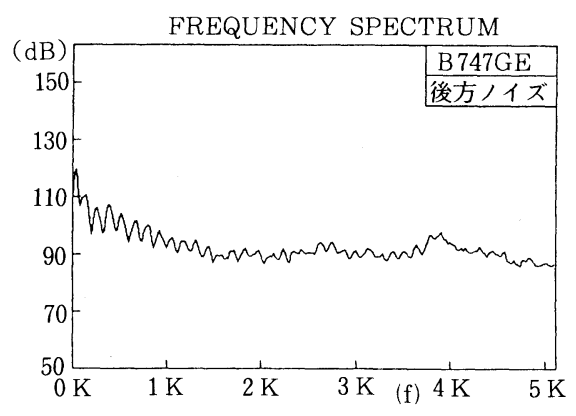

図ー6 B 747GEのパワースペクトラム（昭和60年 9 月） 
表 5 エンジン別の判別結果（判別関数作成には全く 関係のない未知デー夕についての判別率[\%])

\begin{tabular}{|l||r|r|r|r|l|l|}
\hline エンジンタ & JT8D-15 & JT8D-209 & JT9D系 & CF6系 & RB211-22B & DART542 \\
\hline JT8D-15 & $100.0 \%$ & & & & & \\
\hline JT8D-209 & $50.0 \%$ & $50.0 \%$ & & & & \\
\hline JT9D系 & $7.1 \%$ & $3.6 \%$ & $82.2 \%$ & $7.1 \%$ & & \\
\hline CF6系 & $8.1 \%$ & & & $91.9 \%$ & & \\
\hline RB211-22B & & & & & $100.0 \%$ & \\
\hline DART542 & & & & & & $100.0 \%$ \\
\hline
\end{tabular}

知データを入力した場合，全体の判別率が $86.5 \%$ と実 用上差し支えない值が得られた，さらに，異なる機種 でも同一エンジンを搭載している場合があるので，エ ンジンごとの判別を行った結果, 全体で $92.3 \%$ 判別 率であった。

本論文では, 判別関数の作成以外は, パーソナルコ ンピュータで計算処理したが, この方法では, 騒音デー 夕を取りながら，同時に判別関数をより正確なものに 更新していくことができないため,できるだけ気象条 件や航空機の運用方法など, 判別率を悪化させる要素 とは関係のない判別関数をあらかじめ作成しておく必 要がある. あるいは，それらの要素をパラメータに加 えて判別関数を作成することにより, 判別率がさらに 向上するものと考えられる. また, B-737のように 直距離のばらつきの大きいデー夕については, バンド レベルの比をとることによりデータを正規化し，判別 率を上げることあ可能と思われるが, 今回検討しなかっ た.さらに, 離陸機の機種判別については, 現在作業 を進めているところである.

\section{参考 文 献}

1 ) 寺田孝守, 小山雅寛, 片岡昇, 水谷博“航空機騒音のパ ターン認識によるエンジン推力の推定に関する研究 ” 昭和 61年度日本音響学会秋季研究発表会講演論文集 pp. 491 492

2 ）奥野忠一, 久米均, 芳賀敏郎, 吉澤正 “多変量解析法” 1980. 日科技連 pp. $259 \sim 322$

3 ) 中田明彦, 片岡昇, 水谷博 “航空機騒音による機種識別 に関する研究” 昭和56年度日本音響学会春季研究発表会講 演論文集 pp. $13 \sim 14$

4 ）山田佳邦, 東健二, 片岡昇, 水谷博 “ 大阪国際空港着陸 時の航空機騒音による機種識別に関する研究” 昭和 59 年度 日本音響学会秋季研究発表会講演論文集 pp. 319 320

5 ) 田中豊, 垂水共之, 脇本和昌 “ パソコン統計解析ハンド ブック III "1986. 共立出版 pp. 71〜159

6 ) Terrill W. Putnam, Paul L. Lasagna, and Kenneth C. White "Measurement and Analysis of Aircraft Airframe Noise " AIAA 2nd Aero-Acostics Confernce, Hanpton, Va., March 24 26, 1975

\section{図書案内}

\section{食品衛生法施行 40 周年記念 \\ 「21世紀に向けての食品衛生」}

監修 厚生省生活衛生局食品保健課 - 乳肉衛生課 - 食品化学課

A 5 判 320 頁 上製 特別価格 1,000 円(下300円)

$$
\text { 一主な 内 容一 }
$$

安全で快適な食環境を目ざして(サム計画21)

わが国における動物性食品の衛生対策の現状と展望 今後の食品化学行政

機能性食品一その取組みと新開発食品の保健衛生対策 輸入食品監視体制の現状と課題
都道府県における食品衛生行政の展望 21世紀のわが業界（13団体）

21世紀の食生活に望む

これからの食生活に対する消費者の要望

食品保健分野に㧍ける国際協力の現状と今後 